\title{
๑ே९ \\ Gender, History, and Heritage in Ireland and Scotland: Medieval to Modern
}

\author{
Elizabeth C. Macknight
}

$\mathrm{T}$

This special issue of Historical Reflections/Réflexions Historiques derives from panel sessions for the Irish-Scottish Academic Initiative (ISAI) conference held at the University of Aberdeen in October 2009. ${ }^{1}$ The conference marked the tenth anniversary of the founding of Aberdeen's Research Institute of Irish and Scottish Studies. It was also the first ISAI conference to feature panel sessions dedicated to the study of gender in Irish and Scottish history. The overarching theme of the conference-Global Nations? Irish and Scottish Expansion-encouraged discussion of the ways in which the history and heritage of Ireland and Scotland are interpreted and understood both within those countries and abroad. In the two panels on gender, history, and heritage we sought to interrogate past and present notions of Irish and Scottish identity through the lens of gender by bringing together speakers from universities and the heritage sector.

Anniversaries often generate public debate about the nature and role of history and its relationship to national identity. In North America, Australia, and France, such debate was given momentum by significant anniversaries during the late 1980s and early 1990s. The 500th anniversary of Columbus's arrival in the New World, the 200th anniversary of white settlement at Botany Bay, and the 200th anniversary of the French Revolution saw a range of events and initiatives inspired by the theme of commemoration. In the lead-up to these anniversaries, motives for reflecting upon the relationship between history and national identity have been as varied as the commemorative events and initiatives themselves. For historians and their publishers, significant anniversaries open up new opportunities to expand the audience for works of history. For politicians, meanwhile, a party for electors with a bit of cultural glitter offers a seemingly useful distraction from the intractable problems of government usually featured in the media. Yet, as with most parties, questions about who is invited and who is excluded can rise like so many bubbles in a champagne bottle, bursting forth into the public arena before you can say "bon anniversaire."

Just as anniversaries provide good opportunities for drinking champagne, so they are useful to historians for provoking some general reflec- 
tions on their discipline. The issue of exclusion is hardly an unfamiliar one to those who study the lives of women in the past. It is also an issue that has begun to receive attention from scholars concerned with men's experiences and masculinity. Gender, along with other categories such as race and class, offers a tool for investigating the ways in which men and women's differing experiences help to shape the relationship between history and national identity. By examining changing definitions of citizenship, for example, we can begin to unravel the complex connections between gendered identities and national identities in both the past and the present. This type of inquiry used not to be deemed significant. Fortunately, although the issue of exclusion remains an important topic for debate-and not only where based on sex-gender history is, these days, more often than not included rather than excluded from research agendas, tertiary curricula, and publishers' lists.

The extent to which the public asks questions about men and women's contributions to the relationship between history and national identity depends more on public expressions of history than on university courses. How are the lives of men and women represented and interpreted at heritage sites, in museums, in galleries, in state-owned residences-indeed all the places that might attract someone with an interest in finding out about "history"? Visiting such places may alter our perceptions and improve our understanding, or we may emerge with not much new knowledge or appreciation at all. Historians have, on the whole, devoted less time and attention to the relationship between heritage and national identity than one might expect, while those in the heritage industry have perhaps been too keen to define the "national heritage" without addressing the relevant historical debates. Shifting the focus from national identity to gender creates new possibilities. Thus, coming face to face with a specific heritage object-perhaps an early clothes wringer or a cane for punishing schoolboys-can arguably do more to prompt reflection on men and women's differing experiences than any carefully constructed historical argument in a scholarly journal. Students may even think so.

This special issue presents a range of perspectives on gender, history, and heritage from within and outside academia. What questions are seen to be important by professionals within the heritage industry, including historical archaeologists, curators of museum displays, and managers of heritage properties? How do these questions differ from those addressed by historians, especially within university history departments, in relation to research priorities and curricula? To what extent are communities involved in setting the agenda for discussion of history and heritage? The issue draws together contributions from senior scholars, a heritage interpreter, early career researchers, and an historian engaged in knowledge transfer with community organizations. Together the articles cover a broad time period, spanning some nine centuries from the Middle Ages to the present day.

One of the central analytical threads running through the issue concerns the processes of creating, distorting, and interpreting "the historical record" 
for Ireland and Scotland. The freedom to tell one's own story, the power to influence future tellings, is not spread evenly through any society. These articles all demonstrate that gender is implicated, along with other factors such as class, race, and sexuality, in the processes and rationales that determine the kinds of stories that are told, and in the preservation or destruction of historical evidence of all types. Why might men and women, as historical agents, collude in or resist those processes and rationales? To what extent is it possible to interpret "the historical record" from the perspective of what is missing, rather than what it contains?

The first two articles by Linda E. Mitchell and Maryann Valiulis take up this thread through the study of texts about Ireland and the Irish people. Both authors are concerned with the ways in which "Irish-ness" has historically been defined in sexualized and gendered terms. They unpack the meanings behind the selective use of language, applying post-colonial analyses to a range of very different texts-three medieval and one modern-to explore cultural anxieties about Ireland's relationship with England expressed within those texts and in readers' responses to them.

Mitchell's article focuses on three polemical works: an ethnography of Ireland written by a Cambro-Norman cleric, an historical poem written to celebrate the success of the Cambro-Norman conquerors over the Irish, and the 1367 Statutes of Kilkenny. In the context of conquest and settlement, Mitchell argues, "Irish-ness" was represented as "Otherness," separate from and inferior to "English-ness." A classic expression of this comes from Gerald of Wales, a twelfth-century visitor, in his description of Ireland's inhabitants: "a barbarous people, literally barbarous. Judged according to modern ideas, they are uncultivated." Mitchell identifies the 1367 Statutes of Kilkenny as the hardening into law of a centuries-long endeavor through language to position the English as male and the Irish as female in response to fears that long-standing settlement families were appropriating Irish behavior.

Move forward to the twentieth century and there are echoes of Gerald of Wales's assessment of the Irish in W. B. Yeats's interview with the Manchester Guardian on 22 August 1928, in the context of debates over a proposed Censorship Bill. Yeats attacks the Irish as "the most uncultivated of races" on the grounds of the low standards of Irish education and poor reading habits. This sentiment quickly found its way into the Irish Statesman, which deplored moves to enact censorship that would make the country "the butt of all the wit, sarcasm, and irony inside and outside the Irish Free State." Those who opposed censorship, including the outspoken senator Sir John Keane, a member of the Anglo-Irish Ascendancy, were seen to be anti-nationalist, anti-Catholic, and using a rhetoric that was reminiscent of Ireland's colonial past. There was angry retaliation to the arguments made by Yeats and Keane from those who saw in the anti-censorship campaign "great harm done to Ireland, not only in the minds of foreign people but in the minds of some of our own people who live abroad." Valiulis examines the debate on the Censorship Bill to illuminate the Irish concern with national image. She then 
turns to the 1942 work, The Tailor and Ansty, by English author Eric Cross, which in the eyes of nationalist Ireland "threatened to resurrect the degrading images to which they had been subjected as a colonial people" - that is, images encapsulated as early as 1180 and still resonant more than eight hundred years later.

The next two essays, by Rosalind Carr and Sonja Tiernan, examine the processes of creating, distorting, and interpreting "the historical record" by focusing on the lives of individual women in eighteenth-century Scotland and twentieth-century Ireland.

Carr's article draws on research in the archives of Scottish noble families to illustrate the ways in which three noblewomen-Katherine Hamilton, Duchess of Atholl; Katherine Skene, Lady Murray; and Anne Hamilton, Duchess of Hamilton-became central actors in Scottish political life by opposing Parliamentary Union with England in 1707. Carr argues that each of these noblewomen negotiated "complex interactions of status and gender" that informed their involvement in politics. Anne Hamilton, for example, relied on her son James to represent the Hamilton family interest as a peer in the Scottish Parliament. However, she also held significant political power in her own right, coordinating anti-treaty petitions and public demonstrations in areas of Scotland under the Hamilton family's control and influence. In Lanarkshire, where Hamilton Palace is located, Anne Hamilton held the position of sheriff. Although often removed from the cities of Edinburgh and London, Carr's subjects made interventions to the debates occurring in the parliament, as well as exercising power locally on and around their landed estates. This portrayal of three noblewomen's engagement in early eighteenth-century politics seeks to break down the artificial division between "public" and "private" spheres that perhaps partly explains the lack of attention from some Scottish historians to women's political activities. Carr not only shows the capacity of her female subjects to negotiate a masculine political culture on their own terms, but she also makes an incisive statement about the need for more well-rounded portraits of upper-class men that pay attention to male experiences of intimacy and family life.

Intimacy, emotion, and politics also combine in Tiernan's article on the twentieth-century Irish poet, playwright, and radical political activist, Eva Gore-Booth. The considerable literary output of Gore-Booth-she published nineteen volumes of poetry, philosophical prose, and drama-has been mostly out of print since the 1930s and has not received a great deal of scholarly attention. As Tiernan suggests, there are a number of ways this might be explained including the overshadowing reputation of her younger sister Constance, later Countess Markievicz, who devoted her life to fighting for Irish independence from Britain and was the first woman to be elected to the British House of Commons. Yet Gore-Booth also had formidable energy for and success in campaigning. The causes she supported-pacificism, Irish nationalism, women's suffrage, trade union equality-might seem at odds with her aristocratic birth. She championed the rights of women workers 
such as barmaids, circus performers, and flower sellers. Tiernan provides a critique of the accounts of previous biographers and commentators who have ignored, trivialized, or misrepresented Gore-Booth's most significant relationship, that with Esther Roper. The two women were life partners in every sense. Their intellectual collaboration led to the founding of the journal Urania, which was privately printed and circulated from 1916 until 1940. This journal argued for the elimination of sex/gender definitions and the reformation of the categories of male and female into one ideal feminine form. Tiernan contends that biographers' discomfort with discussing lesbian sexuality has led to the misnaming of Gore-Booth's relationship with Roper and the misreading of her literary and philosophical work, which included such radical views of gender.

A second analytical thread in this issue concerns the associations and meanings embedded in place or space. To what extent does gender play a role in the special connections between people and a place or space? Do men and women share the same social or spiritual values and responsibilities for preservation in relation to sites or items of cultural significance? How is gender implicated in the meanings, symbolic qualities, and memories ascribed to a place, space, or artifact through interpretation?

Nicole Deufel, whose professional expertise and interests lie in heritage interpretation, draws on her experiences working at the National Trust for Scotland's Culloden Battlefield Visitor Centre to explore public reactions to storytelling presentations focusing on women. As learning manager at the Centre, which opened in 2007, Deufel was responsible for live interpretation to help visitors better understand the history and heritage of the 1745 Jacobite Rising, including its famous last battle at Culloden. As Deufel explains, the task of developing and implementing a program of live interpretation concerning women's roles in the Jacobite Rising also became a learning curve for her. Visitors' reactions to women-specific content ranged from signs of boredom to frank hostility. Why? In answering this question Deufel taps into the literature on interpretation at battle sites, war museums, and war memorials around the world. "Most studies that examine the ways in which women are represented in war interpretation report representations of women as passive victims or within other stereotypical roles that reinforce notions of masculinity and war as a masculine domain." In her attempts to challenge such representations of women Deufel ran up against the difficulties of appearing to contradict received wisdom about the battle of Culloden. She found, as other studies have also indicated, that "expectations, prior knowledge, and the social context of visitors" can substantially limit their receptiveness to new ideas about history and heritage. The role of the interpreter in revealing the meaning or significance of a site also entails negotiation with what visitors perceive the meanings and significance to be. Might Deufel have encountered less resistance to women-specific presentations if there were more books written by professional historians on women in the Jacobite rising? 
From Deufel's presentation and interpretation of a battle site we move to Catherine O'Byrne's article on oral history and the commemoration of the Piper Alpha disaster, which occurred on 6 July 1988. The explosion of the oil platform in the North Sea killed 167 men. A battle ensued of an altogether different nature from the battle of Culloden yet one that was also characterized by male and female participation and can be fruitfully analyzed through the lens of gender. O'Byrne argues, "Although the disaster itself was first and foremost a male experience, the battle for commemoration was fought—on the families' side at least—predominantly by women. Women for the most part were the ones who dealt with the grief that the disaster caused." Her article examines, through evidence from oral history interviews, the differing meanings that "commemoration" of the Piper Alpha disaster had for those within the oil industry. "For women, commemoration was about creating a memorial as a site for grieving. For men, commemoration was about seeking justice and the continuing fight to improve safety." O'Byrne also investigates the ways in which oil companies and the media sought to manipulate memories of the Piper Alpha disaster, as well as the tactics of individuals and families to resist such manipulation. An important part of this resistance was the drive to establish a memorial in Aberdeen, which was successful: the Piper Alpha memorial, designed by artist Sue Jane Taylor, stands in Aberdeen's Hazelhead Park today. Visitors to this site, no less than visitors to Culloden Battlefield, arrive with their own expectations and prior knowledge of the history and heritage of the oil industry. In O'Byrne's article the stories of the women are told in their own words.

A third analytical thread that links the articles in this issue is that of heritage as perceived by communities. Who determines the cultural significance of the heritage that is valued in a community? To what extent does gender inform the process of ascribing value to heritage sites or artifacts? How do questions of national heritage and identity intersect with community values or gender issues? Valiulis's article shows that in the Irish debates over censorship there were fears that, in the rush to ban "unsuitable texts," the procensorship faction was undermining the cultural significance of Ireland's "great literature." Deufel's article is attentive to the role of the National Trust for Scotland in providing a formal framework for determining the cultural significance of sites. Elizabeth Macknight's article focuses on archives relating to communities in Scotland and the Scottish islands that have so far been little exploited by historians, but are appreciated by locals for the possibilities they open up to showcase heritage and attract tourism. The archives of cooperatives in Scotland and the Angus Macleod archive on the island of Lewis provide case studies of the involvement of communities in identifying, and seeking to promote and make available, records and artifacts that represent their heritage. Macknight compares the differing perceptions of historians, archivists, and community organizations on the "value" of archives and argues for the development of closer working relationships between these interest groups in financially straightened times. 
A key point that emerges from Macknight's article is the role of digital technologies in challenging assumptions about what is "culturally significant" and therefore worth keeping. Historians, who mostly work in libraries and archives where evidence seems to be safely preserved for interpretation, are now confronting a world in which countless electronic records are destroyed every second. This is also a world in which researchers increasingly work from photographic images of documents and artifacts, whether or not they have had access to the original items. This brings us back to the issue of creating, distorting, and interpreting "the historical record" for Ireland and Scotland. In the age of Internet communication it seems that everyone is free to tell his or her own story. How do we ensure equality of opportunity to influence future tellings if the resources for capturing electronic information are not spread evenly through society? When heritage "goes online" what happens to our notion of authenticity?

Decisions about the conservation of documents, artifacts, buildings, and sites, are no less political today than they were a century ago or still further back in time when heritage-and the national identity it supported-was white, male, and ruling class. In Ireland and Scotland, like elsewhere in the world, heritage is inescapably tied to the past and used to define an ongoing national identity. History, meanwhile, involves the recognition that what we see in the past is informed by our modern concerns. From the Middle Ages to the twenty-first century, women and men from all social backgrounds have contributed to making Ireland and Scotland "global nations," cultivating and promoting distinctive identities while simultaneously receiving ideas and influences from other parts of the globe. The evidence we have of women and men's lived experiences in Ireland and Scotland is partial and full of silences and ambiguities. Historians and heritage interpreters do well to reflect together on what can be known, as well as what is absent from the historical record. It is important that we continue to reflect, for, in the words of the poet James McAuley, "What we omit, we teach will not be missed."

\section{Notes}

1. ISAI was set up in 1995 as a formal link between universities in Scotland and Ireland. Members include the University of Aberdeen, the University of Strathclyde, the University of Edinburgh, Queen's University, Belfast and Trinity College, Dublin. 